\title{
STUDY OF FINGERPRINT PATTERNS IN RELATION TO GENDER AND BLOOD GROUP
}

\author{
Bandameedi Lakshmi Narayana1, Yerukala Komera Chinna Rangaiah², Mohammed Abdul Khalid ${ }^{3}$ \\ ${ }_{1}^{1}$ Professor, Department of Forensic Medicine, Kurnool Medical College, Kurnool, Andhra Pradesh. \\ ${ }^{2}$ Assistant Professor, Department of Forensic Medicine, Kurnool Medical College, Kurnool, Andhra Pradesh. \\ ${ }^{3}$ Assistant Professor, Department of Forensic Medicine, Viswabharathi Medical College, R.T. Nagar, \\ near K. Nagalapuram, Kurnool, Andhra Pradesh.
}

\section{ABSTRACT}

A fingerprint is an impression left by the friction ridges of a human finger. Fingerprint patterns are unique in each individ ual and the chance of two persons having identical fingerprints is about one in 64 thousand millions. The fingerprint ridges formed during foetal period do not change their course or alignment throughout the life of an individual. Out of many blood grouping systems available, ABO and Rh systems are the most important and are considered for the present study. Due to the immense potential of fingerprints as an effective method of identification an attempt has been made in the present work to analyse their correlation with gender and blood group of an individual. This study was carried out on 100 subjects ( 50 male and 50 female) having different ABO blood groups and belonging to different age groups. All the 10 fingerprints were taken and divided into loops, whorls, arches and composite. Results show that loops are most commonly found pattern followed by whorls, arches and composite. Loops are predominant in males whereas whorls and arches are seen more in females. Composites being in same proportion in both sexes. Highest frequency of loops was seen in 0 positive blood group followed by B positive. Among loops ulnar loops were predominant.

\section{KEYWORDS}

Fingerprints, Loops, Whorls, Arches, Blood Group.

HOW TO CITE THIS ARTICLE: Narayana BL, Rangaiah YKC, Khalid MA. Study of fingerprint patterns in relation to gender and blood group. J. Evolution Med. Dent. Sci. 2016;5(14):630-633, DOI: 10.14260/jemds/2016/144

\section{INTRODUCTION}

Identity is asset of physical characteristics, functional or psychic, normal or pathological that defines an individual. The term Identity, also called sameness is defined as whatever makes an entity definable and recognizable. The various methods by which identity of a person can be known include fingerprints foot prints, bite marks, lip prints, DNA profiling, iris imaging, etc. ${ }^{1} \mathrm{~A}$ fingerprint is an impression of the friction ridges of all or any part of the finger. A friction ridge is a raised portion of the epidermis on digits or on the palmar and plantar skin. These ridges are also referred to as 'dermal ridges' or 'dermal papillae.'

Primary ridge development occurs along the basement membrane and becomes visible in histological foetal preparations between 12-16 weeks of embryonic development and their formation gets completed by the $14^{\text {th }}$ week, i.e. about the $6^{\text {th }}$ foetal month. The combined effect of heredity and environmental influence produces stress and tension on the patterns growth during foetal life. ${ }^{2}$ The ridges thus formed during the foetal period do not change their course or alignment throughout the life of an individual until destroyed by decomposition of the skin after death. ${ }^{3}$ Fingerprint is one of the most interesting, reliable and unique feature of human body. No two fingerprints are exactly alike.

Fingerprints follow the Locard's principle of exchange. The secretions in the fingerprints contain residues of various chemicals and their metabolites, which can be detected and used for forensic purposes. ${ }^{4}$

Financial or Other, Competing Interest: None.

Submission 30-12-2015, Peer Review 28-01-2016,

Acceptance 03-02-2016, Published 17-02-2016.

Corresponding Author:

Dr. Bandameedi Lakshmi Narayana,

Professor and HOD, Department of Forensic Medicine,

Kurnool Medical College,

Kurnool-518002, Andhra Pradesh.

E-mail: hodfmkmcknl@gmail.com

DOI: 10.14260/jemds/2016/144
Fingerprint identification, also referred to as dactyloscopy is the process of comparing questioned and known friction skin ridge impressions from fingers, palms, and toes to determine if the impressions are from the same finger or palm and toe. Medicolegal importance of fingerprinting includes identifying the criminal, in cheques, in bank notes or passports as a means of identification, in case of mass disasters, to prevent impersonation, in case of accidental exchange of new born infants and to identify unknown corpses.

Blood group system was discovered in 1901 by Karl Landsteiner. A blood type (Also called a blood group) is a classification of blood based on the presence or absence of inherited antigenic substances on the surface of RBC's. The two most important ones are $\mathrm{ABO}$ and the Rh system. The $\mathrm{ABO}$ type is further divided into $\mathrm{A}, \mathrm{B}, \mathrm{AB}$ and $\mathrm{O}$ groups according to the presence of corresponding antigen in plasma. Rhesus system is classified into Rhesus positive ( $\mathrm{Rh}+\mathrm{ve})$ and Rhesus negative (Rh_ve) according to the presence or absence of $D$ antigen. ${ }^{5}$

Due to the immense potential of fingerprints as an effective method of identification an attempt has been made in this study to analyse fingerprint patterns, their correlation with gender and blood group of an individual and also to determine the distribution of different fingerprint patterns among population of Tirupati region.

\section{MATERIALS AND METHODS}

After taking permission from the Member Secretary, Institutional ethical committee of S V Medical College, Tirupati, the study was conducted in Department of Forensic Medicine, S V Medical College, Tirupati, over 100 subjects of both sex and of different age groups. A proper informed written consent was taken from the participants. The study included the samples of subjects who definitely volunteered and were selected without gross variations in their built and nourishment. 
Cases where there was any evidence of disease and injury of the fingertips that was likely to cause a change in the fingerprint pattern (Leprosy, scars of the fingertips, lacerations over fingers) were excluded from the study. The subjects were asked to wash and dry their hands to remove dirt and grease.

For collection of fingerprint, a plain plastic plate of $12 \times$ 6 inches was cleaned and uniformly smeared with a thin layer of black printer's ink (Kores quick drying duplicating ink) by using the inking roller.

The finger bulbs were rolled on the glass slab "the thumbs were rolled towards the subjects body and the fingers were rolled away from the body, i.e. thumb in fingers out method." And then the rolled impression of each finger was obtained in the allotted space for that finger on the proforma. In this way for each and every individual the entire prints of ten fingers were prepared. Special care was taken to avoid smudging of the print. Only rolled prints were taken, i.e. no plain prints.

The details of the subjects like Age, Sex and Demographic details were also noted in the proforma along with the fingerprints. Blood groups were secured from their ID cards. Each subject was assigned a serial number.

After taking the prints, they were analysed under a magnifying lens. Various characteristic features of the prints like core, delta, bifurcation, island formation, etc. were analysed in four groups and photographs taken whenever necessary.

\section{RESULTS}

A keen and detailed fingerprint study with proper technique was carried out in Department of Forensic Medicine and Toxicology, SV Medical College, Tirupati, during the period of June 2011 to June 2012. Total no. of 100 subjects includes equal number of males and females.

\begin{tabular}{|c|c|c|c|}
\hline Blood Group & Male & Female & Total \\
\hline $\mathrm{A}$ & $6(6.0 \%)$ & $4(4.0 \%)$ & $10(10.0 \%)$ \\
\hline $\mathrm{AB}$ & $1(1.0 \%)$ & $4(4.0 \%)$ & $5(5.0 \%)$ \\
\hline $\mathrm{B}$ & $19(19.0 \%)$ & $15(15.0 \%)$ & $34(34.0 \%)$ \\
\hline $\mathrm{O}$ & $24(24.0 \%)$ & $27(27.0 \%)$ & $51(51.0 \%)$ \\
\hline Total & $\mathbf{5 0}$ & $\mathbf{5 0}$ & $\mathbf{1 0 0}(\mathbf{1 0 0} \%)$ \\
\hline \multicolumn{4}{|c|}{ Table 1: Distribution of blood groups of } \\
subjects according to gender \\
\hline
\end{tabular}

Table 1 shows distribution of blood groups of subjects according to gender. Majority of the subjects (51, 51\%) belonged to blood group 0 , followed by B $(34,34 \%)$, A (10, $10 \%)$ and $A B(5,5 \%)$. Blood group 0 had the highest frequency in both males and females followed by blood groups B, A and $\mathrm{AB}$.

\begin{tabular}{|c|c|c|}
\hline Blood Group & Rh positive & Rh negative \\
\hline A & 8 & 2 \\
\hline B & 32 & 2 \\
\hline AB & 5 & 0 \\
\hline O & 49 & 2 \\
\hline Total & 94 & $\mathbf{6}$ \\
\hline \multicolumn{2}{|c|}{ Table 2: Distribution of blood groups of } \\
subjects according to Rh factor \\
\hline
\end{tabular}

Table 2 shows distribution of blood groups of subjects according to $\mathrm{Rh}$ factor.
Majority of the subjects were Rh positive $(94,94 \%)$ and 6 were Rh negative. 0 group $(49,49 \%)$ had the highest frequency among $\mathrm{Rh}$ positive followed by B (32, 32\%), A (8, $8 \%)$ and blood group $A B(5,5 \%)$ had the least frequency. Among Rh negative subjects, blood groups $\mathrm{A}, \mathrm{B}$ and $\mathrm{O}$ were equally predominant with $2 \%$. $A B$ negative group was not found in study population.

\begin{tabular}{|c|c|c|}
\hline Fingerprint Pattern & Total Number & Percentage \\
\hline Loops & 566 & $56.6 \%$ \\
\hline Whorls & 337 & $33.7 \%$ \\
\hline Arches & 79 & $7.9 \%$ \\
\hline Composite & 18 & $1.8 \%$ \\
\hline Total & $\mathbf{1 0 0 0}$ & $\mathbf{1 0 0} \%$ \\
\hline $\begin{array}{c}\text { Table 3: Distribution of primary fingerprint } \\
\text { patterns among the subjects }\end{array}$ \\
\hline
\end{tabular}

Table 3 shows distribution of primary fingerprint patterns of all the fingers of both hands of all the subjects. Loops had the highest frequency of $56.6 \%$ followed by whorls with $33.7 \%$, arches with $1.8 \%$ and composites showed the least number with $1.8 \%$.

\begin{tabular}{|c|c|c|}
\hline Fingerprint Pattern & Male & Female \\
\hline Loop & $290(51.23 \%)$ & $276(48.76 \%)$ \\
\hline Whorl & $163(48.36 \%)$ & $174(51.6 \%)$ \\
\hline Arches & $38(48.10 \%)$ & $41(51.8 \%)$ \\
\hline Composite & $9(50.0 \%)$ & $9(50.0 \%)$ \\
\hline \multicolumn{2}{|c|}{ Table 4: Distribution of fingerprint } \\
patterns according to gender
\end{tabular}

Table 4 shows distribution of fingerprint patterns according to gender. Frequency of loops were found to be higher in males (51.23\%) compared to that of females $(48.76 \%)$. Whorls and arches were seen higher in females compared to males. Composites showed equal incidence in both sexes.

\begin{tabular}{|c|c|c|c|c|c|c|c|c|}
\hline \multirow[b]{2}{*}{$\begin{array}{c}\text { Fingerprint } \\
\text { Pattern }\end{array}$} & \multicolumn{8}{|c|}{ Blood Groups } \\
\hline & $\begin{array}{c}\text { A } \\
+ \text { +ve }\end{array}$ & $\begin{array}{l}\text { A - } \\
\text { ve }\end{array}$ & $\begin{array}{c}\text { B } \\
+ \text { +ve } \\
\end{array}$ & $\begin{array}{l}\text { B - } \\
\text { ve }\end{array}$ & $\begin{array}{c}\text { AB } \\
+ \text { ve } \\
\end{array}$ & $\begin{array}{l}\mathrm{AB} \\
\text {-ve }\end{array}$ & $\begin{array}{c}0 \\
+\mathrm{ve} \\
\end{array}$ & $\begin{array}{c}0 \\
\text {-ve }\end{array}$ \\
\hline Loops & 32 & 12 & 183 & 11 & 26 & 0 & 296 & 6 \\
\hline Whorls & 35 & 5 & 110 & 6 & 15 & 0 & 156 & 10 \\
\hline Arches & 10 & 2 & 22 & 2 & 8 & 0 & 32 & 3 \\
\hline Composite & 3 & 1 & 5 & 1 & 1 & 0 & 6 & 1 \\
\hline
\end{tabular}

Table 5 shows distribution of fingerprint patterns among different blood groups with Rh factors. Loops had the highest frequency in all $\mathrm{Rh}$ positive and $\mathrm{Rh}$ negative blood groups except $\mathrm{A}+\mathrm{ve}$ and $\mathrm{O}$-ve blood group where whorls were dominant, followed by whorls and arches. 0 positive blood group had the highest number of all the patterns among $\mathrm{Rh}$ positive blood groups. Among Rh negative, loops were more in blood group A, whorls and arches in $\mathrm{O}$ blood group. Composites were more in $\mathrm{O}+$ ve group, followed by $\mathrm{B}+$ ve blood group.

\section{DISCUSSION}

Fingerprints are the friction ridge impressions of pattern formed by papillary or epidermal ridges of terminal part of the finger. The first ever work for dermatoglyphics was done somewhat around 3000 years back when Chinese used fingerprints to sign legal documents. 
Herschel used fingerprints for personal identification in India as a sign in contracts.

The advantages of using fingerprint patterns as a means of identification is that it can be filed and saved and retrieved when needed. The system of classification which is in use even today is a modification of system proposed by Sir Francis Galton and was modified by Sir Edward Henry. The classification is known as Henry Galton method or Henry's system of classification. ${ }^{6}$ This system of classification is most efficient and is in almost universal use. The four basic fingerprint patterns, which are used in this study are loops (65-67\%), whorls (25-30\%), arches (6-7\%) and composites (3-4\%) (Fig. 1). Composite pattern is the rarest. A loop is that type of fingerprint pattern in which one or more of the ridges enter on either side of the impression, re-curve, touch or pass an imaginary line drawn from the delta to core and terminates or tends to terminate on or towards the same side of the impression from where ridge or ridges enter.

A loop has one and only one delta. Loops are subdivided into two main types - radial loop and ulnar loop according to their positioning and the flow of the ridges. Radial loop is so called because the ridges flow or terminate in the direction of radius bone of the forearm. Ulnar loop is so called because the ridges flow or terminate in the direction of ulnar bone of the forearm. A whorl is characterised by a circular pattern having one or more ridges revolve around the core making a complete circle. The whorl is that type of pattern in which at least two deltas are present with a recurve in front of each. The subdivision of whorl pattern is as follows 1 .

Plain Whorl 2. Central Pocket Loop 3. Double Loop i. Lateral Pocket Loop ii. Twinned Loop 4. Accidentals. Arches can be classified into plain arch and tented arch. Plain arch is made up of ridges lying one above the other. Tented arch consists of one upthrusting ridge, which tends to bisect superior ridges at right angles. Composites are the complex patterns usually composed of different configurations in one pattern, such as tented arch and loop or loop and whorl etc. or any other such combinations, which do not fit appropriately in the basic pattern types.
Dr. Rastogi et al. in 2010 had conducted a similar study on 200 medical students of Kasturba Medical College, Mangalore. ${ }^{7}$ Bhavana et al. in 2013 completed a study on 200 individuals from Hubli, Dharwad, Karnataka. ${ }^{8}$ The results of these studies are compared with the results of the present study.

\begin{tabular}{|c|c|c|c|c|c|c|}
\hline \multirow{2}{*}{$\begin{array}{c}\text { Blood } \\
\text { Group }\end{array}$} & \multicolumn{2}{|c|}{ Bhavan D } & \multicolumn{2}{c|}{ Rastogi P } & \multicolumn{2}{c|}{$\begin{array}{c}\text { Present } \\
\text { Study }\end{array}$} \\
\cline { 2 - 7 } & $\begin{array}{c}\text { Rh } \\
\text { +ve }\end{array}$ & $\begin{array}{c}\text { Rh - } \\
\text { ve }\end{array}$ & $\begin{array}{c}\text { Rh } \\
\text { +ve }\end{array}$ & $\begin{array}{c}\text { Rh - } \\
\text { ve }\end{array}$ & $\begin{array}{c}\text { Rh } \\
\text { +ve }\end{array}$ & $\begin{array}{c}\text { Rh } \\
\text {-ve }\end{array}$ \\
\hline $\mathrm{A}$ & $19.5 \%$ & $1.5 \%$ & $26.5 \%$ & $1.5 \%$ & $8 \%$ & $2 \%$ \\
\hline $\mathrm{B}$ & $35 \%$ & $2 \%$ & $30.5 \%$ & $1.5 \%$ & $32 \%$ & $2 \%$ \\
\hline $\mathrm{AB}$ & $6.5 \%$ & $0.5 \%$ & $4.5 \%$ & $0 \%$ & $5 \%$ & $0 \%$ \\
\hline $\mathrm{O}$ & $34 \%$ & $1 \%$ & $34.5 \%$ & $1 \%$ & $49 \%$ & $2 \%$ \\
\hline Total & $\mathbf{9 5 \%}$ & $\mathbf{5 \%}$ & $\mathbf{9 6 \%}$ & $\mathbf{4 \%}$ & $\mathbf{9 4 \%}$ & $\mathbf{6 \%}$ \\
\hline \multicolumn{6}{|c|}{ Table 7: Distribution of blood groups of subjects } \\
according to Rh factor \\
\hline
\end{tabular}

Table 7 shows comparative study on distribution of blood groups of subjects according to $\mathrm{Rh}$ factor. $\mathrm{Rh}$ positive blood groups dominated in the present study and $\mathrm{AB}$ negative blood group was found to be the rarest. The results were in accordance with the findings from past studies.

\begin{tabular}{|c|c|c|c|}
\hline $\begin{array}{c}\text { Fingerprint } \\
\text { Pattern }\end{array}$ & Bhavana D & Rastogi P & $\begin{array}{c}\text { Present } \\
\text { Study }\end{array}$ \\
\hline Loops & $58.9 \%$ & $60.95 \%$ & $56.6 \%$ \\
\hline Whorls & $29.6 \%$ & $32.55 \%$ & $33.7 \%$ \\
\hline Arches & $11.5 \%$ & $6.5 \%$ & $7.9 \%$ \\
\hline Composite & & $1.8 \%$ \\
\hline \multicolumn{3}{|c|}{ Table 8: Distribution of primary fingerprint } \\
patterns among the subjects \\
\hline
\end{tabular}

Table 8 shows comparative study on distribution of primary fingerprint patterns among the subjects. Loops dominated in all the three studies followed by whorls and arches.

\begin{tabular}{|c|c|c|c|c|c|c|}
\hline \multirow{2}{*}{$\begin{array}{c}\text { Fingerprint } \\
\text { Pattern }\end{array}$} & \multicolumn{2}{|c|}{ Bhavana D } & \multicolumn{2}{c|}{ Rastogi P } & \multicolumn{2}{c|}{$\begin{array}{c}\text { Present } \\
\text { Study }\end{array}$} \\
\cline { 2 - 7 } & Male & Female & Male & Female & Male & Female \\
\hline Loops & $47.83 \%$ & $52.63 \%$ & $47.58 \%$ & $52.42 \%$ & $51.23 \%$ & $48.76 \%$ \\
\hline Whorls & 57.09 & 42.90 & 55.78 & 44.22 & $48.36 \%$ & $51.6 \%$ \\
\hline Arches & $48.26 \%$ & $51.73 \%$ & $44.61 \%$ & $55.38 \%$ & $48.10 \%$ & $51.8 \%$ \\
\hline Composite & \multicolumn{3}{|c|}{ Table 9: Distribution of fingerprint patterns according to gender } \\
\hline \multicolumn{7}{r|}{}
\end{tabular}

Table 9 shows comparative study on distribution of fingerprint patterns according to gender. Loops were more in males and whorls were more in females in the present study, whereas loops were more in males and whorls were more in females in other studies. Arches were more in females in all the three studies.

Frequency of loops was highest in all $\mathrm{Rh}$ positive and $\mathrm{Rh}$ negative blood groups except $\mathrm{A}$ positive and $\mathrm{O}$ negative where whorls were slightly predominant followed by whorls, arches and composites according to the present study. On comparison with other studies like the study done by Bhavana et al. in 2013 and by Dr. Rastogi in 2010, similar findings are observed except for $A$ positive and 0 negative, which shows predominance of whorls.
O positive blood group had the highest number of all the patterns among Rh positive blood groups, which is similar to the study of Dr Rastogi and in contradiction to the study of Bhavana et al. where more number of patterns were seen in $B$ positive group.

In Bhavana D's studies, loops and arches are more in blood group B and whorls are equally dominant in both B and O blood groups. In 2000-2001, Bharadwaja et al. ${ }^{4}$ conducted a study on 300 medical students in Rajasthan. The study reveals that subjects with blood group A have more of loops and those with blood group AB have more of whorls. Study conducted by Sharma et al. ${ }^{9}$ in 2008 shows that blood group 0 have highest frequency of whorls, which is similar to the result obtained in the present study. 


\section{CONCLUSION}

Present study is an attempt to associate fingerprint patterns with gender and blood group of an individual. Fingerprint patterns can be of help in predicting the gender and blood group of an individual. It may help in increasing the authenticity of fingerprints in identification of individuals and solving of crimes. The following results were obtained.

- Loops were the most commonly found pattern and composites the least. In loop pattern the commonest pattern was ulnar loop, which were statistically significant in this original study.

- Blood group 0 positive was the most common and $\mathrm{AB}$ negative was found to be the rarest.

- $\quad \mathrm{Rh}$ positive blood groups were more compared to $\mathrm{Rh}$ negative blood groups, which is proved in this original study and significant based on the statistical data also.

- Blood group B was the most common among Rh positive blood groups followed by $\mathrm{O}, \mathrm{A}$ and $\mathrm{AB}$ blood groups.

- Among $\mathrm{Rh}$ negative $\mathrm{B}$ and $\mathrm{A}$ blood groups were equally dominant followed by $\mathrm{O}$ and $\mathrm{AB}$.

- Loops were highest in males, whorls and arches were highest in females.

- Loops were predominant in all the blood groups except A positive where whorls were dominant.

- Highest number of all the patterns was found in blood group $\mathrm{O}$ and least in $\mathrm{AB}$ among $\mathrm{Rh}$ positive blood groups and statistically proved significant in this original study.

- Composites were least commonly found in all the blood groups.

\section{REFERENCES}

1. Bijlani RL, 1997. Textbook of Physiology. 2nd ed. Blood Groups: 93-94.

2. Cummins $\mathrm{H}$ Palmar. Plantar epidermal ridge configuration (dermatoglyphics) in Europeans and Americans. Am J Phy Anthrop 1926;179:741-802.

3. Surinder Nath, 1984. Finger Print Identification, Gita Press, Delhi, 1-15.

4. Bharadwaja A, Saraswat PK, Agrawal SK, et al. 2004. Pattern of fingerprints in different ABO blood groups. Journal of Forensic Medicine and Toxicology, 21(2):4952.

5. Fingerprint available online at http://en.wikipedia.org/wiki/Fingerprint

6. Pillay VV, 2009. Textbook of Forensic Medicine and Toxicology. 15th ed. Hyderabad. Paras Medical Publishers, 53-94.

7. Dr Rastogi P, Ms Pillai KR. A study of fingerprints in relation to gender and blood group. J Indian Acad Forensic Med 2010;32(1):11-14.

8. Bhavana D, Ruchi J, Prakash T, 2013. Study of fingerprint patterns in relationship with blood group and gender- a statistical review. Res J Forensic Sci, March, 1(1):15-17.

9. Sharma PR, Gautam AK, Tiwari PK, 2008. Dermatoglyphic variations in five ethno-geographical cohorts of Indian populations: a pilot study. The International Journal of Biological Anthropology 2(1):57-66. 